https://doi.org/10.18485/iipe_conv_conf.2021.ch2

\title{
THE ENLARGED MEDITERRANEAN, CHINA'S CENTRIPETAL IMPERIALISM, AND THE CASE STUDY OF THE BALKANS
}

\author{
Matteo Marconi and Francesco Barbaro ${ }^{1}$
}

\begin{abstract}
Understanding China's presence in the Mediterranean can only start by bearing in mind the peculiarity of the region, given its political, cultural, and economic divisions. Considering Westerners' failures based on the theory of the Greater Middle East, we would rather support the concept of an enlarged Mediterranean and analyse it in its various facets. After discussing the main scholarly positions on the topic, we propose an interpretation of China's impact in the region by introducing the concept of centripetal imperialism: pushed by geopolitical reality to project itself beyond its borders, Beijing is ready to offer its capitals in exchange for a penetration that, despite its neo-colonial aspect, does not seek to impose a predetermined political and cultural formula. We then support our view by analysing the case study of the Balkans, which seems to confirm that Chinese investments are primarily driven by economic interests (with problems caused more by planning mistakes rather than by malevolent intentions) and that the Dragon intervenes in the internal affairs of the recipient countries only if strategically necessary.

Keywords: enlarged Mediterranean, China's centripetal imperialism, Balkans.
\end{abstract}

\section{THE ENLARGED MEDITERRANEAN AND ITS GEOPOLITICAL SPACES}

China's presence in the Mediterranean has now become apparent: the new global politics' rules themselves push Beijing (as well as other players)

\footnotetext{
${ }^{1}$ Affiliation: Sapienza University of Rome. matteo.marconi@uniroma1.it; francesco.barbaro@uniroma1.it.
} 
to go beyond its regional space. The international environment does not allow for clear boundaries, leading to new opportunities and new critical issues at the same time. Understanding the possible impacts of the Chinese projection towards Mare Nostrum can only start by considering the identity of the latter.

The Mediterranean, as the theatre of Western culture, has been considered a cohesive area for millennia. However, with the modern age, it has lost its centrality to the benefit of the Atlantic Ocean. As a result, the concept of Mediterranean marginality came to dominate in the twentieth century. ${ }^{2}$ The limits of this interpretation have been confirmed by Westerners' failures to address the regional geopolitical issues.

The EU's indecisiveness worsened the instability, leaving free rein to national interests. European countries have thus delegated their strategic and military responsibilities to NATO, which, despite being aware of the multiplicity of regional threats ${ }^{3}$, has not managed to put forward a comprehensive approach due to international divisions.

The Mediterranean's divisions have been accentuated by the United States under the George W. Bush administration with the adoption of the theory of the Greater Middle East: Mare Nostrum is reduced to a mere passageway between the oceans and a dividing line between the two shores. The grouping of North Africa and the Middle East under the MENA area is based on the idea of a "clash of civilizations" between Westerners and Muslims. ${ }^{4}$

The Greater Middle East was put into question by the theory of the enlarged Mediterranean. Presented as early as the 1980s by Livorno's Istituto di Guerra Marittima, this theory includes the adjacent basins in the current Mediterranean one. ${ }^{5}$ In elaborating it, the Marina militare has resumed at

\footnotetext{
${ }^{2}$ See Andrew Hess, The Forgotten Frontier: A History of the Sixteenth Century Ibero-African Frontier, University Chicago Press, Chicago 1978; Alexandre Koyré, Dal mondo del pressappoco all'universo della precisione, Einaudi, Turin 2000.

${ }^{3}$ See the speech by the then Secretary General of NATO at the 2011 Forum for New Diplomacy: Anders Fogh Rasmussen, NATO and the Arab Spring, Speech by the NATO Secretary General during the Forum for New Diplomacy hosted by Carnegie Europe, Bruxelles, June 1, 2011.

${ }^{4}$ See Samuel Phillips Huntington, The Clash of Civilizations and the Remaking of World Order, Simon \& Schuster, New York 1996.

${ }^{5}$ See Pier Paolo Ramoino, Fondamenti di strategia navale, Edizioni Forum Relazioni Internazionali, Rome 1999. See also Pier Paolo Ramoino, La NATO e il "Mediterraneo
} 
least two criteria presented in the 1930s by the Capitano di Vascello of the Regia Marina, Francesco Bertonelli: 1) because the Mediterranean is an enclosed sea, players compete for the control over it and are interested in everything that happens in it, as evidenced by the international relevance of local conflicts; 2 ) it is necessary to protect bottlenecks in order to ensure the correct and crucial flow of supplies ${ }^{6}$. This is still an issue if one considers that a large portion of global goods and energy resources pass through the Mediterranean, and in particular, through the Suez Canal. ${ }^{7}$

Nevertheless, the multiple spaces of the Mediterranean are dominated by reasons for division. Starting from the political level, apart from the clear distinction between the liberal model of the northern shore and the authoritarian one of the southern shore, the division and the loss of power of the Arab world also emerge. ${ }^{8}$ North Africa and the Middle East are still dealing with the consequences of the "Arab Spring", an expression used by journalists to describe the protests that took place in 2011 against the ruling leaderships in the areas that had lost popular support in recent decades because of the fading away of ideologies and nationalistic pressures and the effects of "socialistic" policies. ${ }^{9}$ An Islamism that considers Western political

allargato": primavera araba, intervento in Libia, partnerships, in "Quaderni del Dipartimento di Scienze Politiche. Università del Sacro Cuore", II, 4, 2013, pp. 73-84; Giorgio Giorgerini, Riccardo Nassigh, La relatività delle forze nell'area del Mediterraneo Allargato, in C. M. Santoro (ed.), II XXI Secolo, Centro Militare di Studi Strategici, Milan 2002.

${ }^{6}$ Francesco Bertonelli, II nostro mare: studio della situazione politica militare dell'Italia nel Mediterraneo, R. Bemporad \& Figlio editori, Florence 1930.

${ }^{7}$ See SRM, MED \& Italian Energy Report. Risorse, flussi e strategie energetiche dell'Italia tra Europa e Mediterraneo. First Annual Report, 2019; SRM, Resilienza e Sviluppo nel Mezzogiorno: settori, aree e linee prospettiche, Report prepared for the Aspen Institute Italia Conference of December 3, 2020 "II Mezzogiorno d'Italia: chiave di rilancio per l'economia italiana?", 2020.

${ }^{8}$ See Salvatore Capasso, Introduzione. I paesi del Mediterraneo tra disuguaglianza e convergenza: sviluppo economico, sostenibilità e migrazioni, in Eugenia Ferragina (ed.), Rapporto sulle economie del Mediterraneo. Edizione 2018, Istituto di Studi sulle Società del Mediterraneo, Rome 2018; Roberto Aliboni, L'evoluzione geopolitica nel Medioriente, in Eugenia Ferragina (ed.), Rapporto sulle economie del Mediterraneo. Edizione 2018, Istituto di Studi sulle Società del Mediterraneo, Rome 2018.

${ }^{9}$ See Alberto Ventura, Le Rivoluzioni prevedibili. Per una analisi storica delle "Primavere arabe", in Guerino D'Ignazio, Nicola Fiorita, Silvio Gambino, Francesco Raniolo, Alberto 
and economic solutions foreign has found its way into traditionalist public opinion, resulting in movements as well as clandestine military organisations. The governments in office reacted with harsh repression, often with the connivance of Western countries, which (especially after the September 11 attacks) regarded them as a source of stability. ${ }^{10}$

Because of the EU's political mistakes, foreign players like China have more possibilities in the Mediterranean. True, Brussels has always attempted to take an interest in the region; in fact, as early as the 1970s, the then-European Economic Community (EEC) finalised bilateral commercial agreements with some southern shore countries" ${ }^{11}$. However, the "Global Mediterranean Policy" launched in 1972 was stopped by the oil shock of the following year. ${ }^{12}$ The Redirected Mediterranean Policy of 1990 and the Euro-Mediterranean Association Agreements at the end of the decade looked like signals of recovery, but the real chance for a turning point was provided by the EuroMediterranean partnership launched by the Barcelona Conference in 1995, whose objectives remained, however, largely unfulfilled. ${ }^{13}$ In 2003, the EU granted the benefits of the internal market to a circle of "friend" countries through the European Neighbourhood Policy (ENP); finally, in 2008, it promoted the Union for the Mediterranean (UfM), focusing on economic

Ventura (eds.), Transizioni e democrazia nei Paesi del Mediterraneo e del vicino Oriente, Edizioni Periferia, Cosenza 2014, pp. 333-344. See also Carlo Almirante, Considerazioni interlocutorie su uno stimolante convegno internazionale, in Guerino D'Ignazio, Nicola Fiorita, Silvio Gambino, Francesco Raniolo, Alberto Ventura (eds.), Transizioni e democrazia..., pp. 401-411.

${ }^{10}$ See Alberto Ventura, Le Rivoluzioni prevedibili...

${ }^{11}$ See Giuliana Laschi, La Cee e il Mediterraneo: I'avvio delle politiche verso i paesi terzi della sponda sud, in Sante Cruciani, Maurizio Ridolfi (eds.), L'Unione Europea e il Mediterraneo. Relazioni internazionali, crisi politiche e regionali (1947-2016), FrancoAngeli, Milan 2017, pp. 89-110.

${ }^{12}$ See Massimiliano Trentin, Le Comunità Europee e gli Stati arabi nei «lunghi anni settanta»: economia, politica e potere, in Sante Cruciani, Maurizio Ridolfi (eds.), L'Unione Europea e il Mediterraneo..., pp. 129-148; Alessandro Isoni, Da Barcellona a Marsiglia. Le politiche dell'Unione europea nel Mediterraneo, in Susanna Cafaro (ed.), Le relazioni euromediterranee. Dai primi accordi all'Unione per il Mediterraneo, ESI, Naples 2013, p. 1 and ff.

${ }^{13}$ See Maria Eleonora Guasconi, La politica mediterranea dell'Unione Europea: I'occasione perduta del partenariato euro-mediterraneo, in Sante Cruciani, Maurizio Ridolfi (eds.), L'Unione Europea e il Mediterraneo... 
practical initiatives and paying less attention to the political dialogue. After the Arab Spring, Brussels reinforced the "more for more" model, depending on social and economic reforms ${ }^{14}$, leading the countries of the southern shore to look for less demanding offers. It is no coincidence that the activities of alternative players have increased in the region.

Turkey has tried to get a Mediterranean projection back ${ }^{15}$, especially after the freezing of its accession to the EU. In 2009, the Minister of Foreign Affairs, Ahmet Davutoğlu, proposed its theory of "strategic depth", according to which the country should take advantage of its position in the Mediterranean, leveraging its mixed identity (European and Muslim) to present itself as a bridge between the West and the East. ${ }^{16}$ Ankara has therefore supported Serraj in Libya and the opposition in Syria ${ }^{17}$, whereas it has been engaged in a thorny dispute with Athens over the extent of their respective Exclusive Economic Zones (ZEEs). ${ }^{18}$

With the annexation of Crimea in 2014, Russian activism has increased, also thanks to the United States' disengagement in the area. At the request

\footnotetext{
${ }^{14}$ See Stefania Panebianco, L'Unione Europea nel Mediterraneo: oltre la primavera araba, in Guerino D’Ignazio, Nicola Fiorita, Silvio Gambino, Francesco Raniolo, Alberto Ventura (eds.), Transizioni e democrazia nei Paesi del Mediterraneo e del vicino Oriente, Edizioni Periferia, Cosenza 2014, pp. 287-310. See also Susanna Cafaro, La dimensione mediterranea nelle relazioni esterne dell'Unione dopo la primavera araba, in "Cultura giuridica e diritto vivente", I, 1, 2014, pp. 1-18.

${ }^{15}$ See Jana Jabbour, Le retour de la Turquie en Méditerranée: la "profondeur stratégique» turque en Méditerranée préet post-printemps arabe, in "Cahiers de la Méditerranée", XLV, 89, 2014, pp. 45-56; Michela Ceccorulli, La dimensione marittima dell'Unione Europea nel Mediterraneo allargato. Opportunità, rischi e prospettive, CeMiSS, Rome 2016, pp. 52-53; Giuseppe Gagliano, Mediterraneo orientale: una disputa geoeconomica e geopolitica, in "Rivista marittima", CLIV, 2, 2021, pp. 48-55.

${ }^{16}$ See Angelo Francesco Carlucci, La Turchia e le "Primavere arabe", in Guerino D'Ignazio, Nicola Fiorita, Silvio Gambino, Francesco Raniolo, Alberto Ventura (eds.), Transizioni e democrazia...; Aleksandr Irkhin, Olga Moskalenko, Russia's Foreign Policy in the Great Mediterranean: Prospects and Constraints, in "Geopolitics Quarterly", XV, 4, 2020, pp. 110-121.

17 See Giuseppe Gagliano, Mediterraneo orientale...

${ }^{18}$ See Fabien Merz, Trouble with Turkey in the Eastern Mediterranean, in "CSS Analyses in Security Policy", 275, CSS ETH Zürich, December 2020, pp. 1-4; Anna Maria Delvecchio, Grecia e Turchia in competizione nel Mediterraneo orientale: il caso emblematico di Cipro, in "Cultura giuridica e diritto vivente", VII, 3, 2020, pp. 1-10.
} 
of President Bashar al-Assad, who relied on historically good relations between the two countries, Putin intervened in its defence in the Syrian civil war in September 2015 (someone underlined that Moscow had its two bases in Tartus and Hmeimim to protect). ${ }^{19}$ Moreover, political and military cooperation with Cairo was strengthened through the sale of weapons. For Russia, Egypt also represented a gateway to Libya, where it supported Haftar. The Kremlin tried to create a Russian balance, promoting a sense of reliability. However, with the attempts to regain influence in the Balkans, Moscow is returning to the Mediterranean with similar objectives (mutatis mutandis) to those of the Cold War. ${ }^{20}$

Another element highlighting the division in the Mediterranean is the religious one: despite the context of post-secularism ${ }^{21}$, the secular model stands strong on the northern shore, whereas the clash between Sunnis and Shiites is an important key to understanding the divisions in North Africa and the Middle East. Power is not strongly legitimised in Sunni-majority countries, except for Turkey and Morocco. Apart from important ramifications in Lebanon and Iraq, most Shiites are in Iran, and the regional politics of these countries is strengthened by a strong mix of civil and religious power. ${ }^{22}$ Arab countries are home to many Christian churches, which are "inaccurately grouped under the expression "Christians of the East"". ${ }^{23}$ Historically, they tolerated them by subduing their believers, as well as the Jews, to the dhimma, a set of restrictive legal provisions provided by Sharia. However, a division is represented by the persecutions suffered by Christians in various local contexts.

${ }^{19}$ See Francesco Cirillo, Interessi russi nel Mediterraneo Orientale, in Mediterranean Sea: Current Trends and Future Challenges, Association of Studies, Research and Internationalization in Eurasia and Africa, "Geopolitical Report", III, 4, 2018, pp. 69-82; Chiara Lovotti, La Russia in Medio Oriente. Una presenza destinata a durare?, in "Osservatorio di politica internazionale", 79, 2018.

${ }^{20}$ See Aleksandr Irkhin, Olga Moskalenko, Russia's Foreign Policy..., p. 120.

${ }^{21}$ See Paolo Naso, L'incognita post-secolare. Pluralismo religioso, fondamentalismi, laicità, Guida Editori, Naples 2015.

${ }^{22}$ See Vali Nasr, The Shia Revival: How Conflicts within Islam Will Shape the Future, W.W. Norton \& Company, New York 2016.

${ }^{23}$ See Antoine Courban, Essere cristiani in Medio Oriente, in "Aggiornamenti sociali", LXVII, 1, 2016, pp. 28-38. See also Bernard Heyberger, Les Chrétiens au Proche-Orient, Payot et Rivages, Paris 2013. 
Finally, economic divisions are also serious in the Mediterranean. It is true that in the last twenty years, the income gap between the two shores has narrowed, also thanks to a higher flow of foreign direct investments (FDI) and an increase in manufacturing activities in the south. However, the economic gap is still considerable and difficult to narrow down, especially when it comes to trade. While proposing an open market, the abovementioned EU initiatives offered European industrial products without accepting the agricultural products of the counterparties ${ }^{24}$. There are also numerous internal inequalities in the North African countries, most notably the rural exodus and a very high urban concentration (above all along the coasts and the rivers), high rates of demographic growth and unemployment, and gaps regarding access to health and education. ${ }^{25}$ Water scarcity and climate change have worsened the situation and have caused the migration flows to increase. As a consequence, the agreements promoted by European countries in recent years have changed their goal, going from selective policies to contrasting ones through a securitarian approach, such as the latest European initiatives (Mare Nostrum, Triton, Frontex, etc.). ${ }^{26}$

\footnotetext{
${ }^{24}$ See Samir Makdisi, Sulle disparità economiche e politiche prevalenti e sulle prospettive di una stretta integrazione di una regione euro-mediterranea, in Eugenia Ferragina (ed.), Rapporto sulle economie del Mediterraneo. Edizione 2018, Istituto di Studi sulle Società del Mediterraneo, Rome 2018; Luca Forte, Giovanni Canitano, Maria Rosaria Carli, Crescita economica, produzione manifatturiera e commercio estero nei paesi del Mediterraneo: differenze e complementarità tra paesi euromediterranei e paesi della sponda sud ed est del Bacino, in Eugenia Ferragina (ed.), Rapporto...

${ }^{25}$ See Anna Maria Ferragina, Giulia Nunziante, Disparità e ineguaglianze tra i territori all'interno dell'area Mediterranea, in Eugenia Ferragina (ed.), Rapporto...

${ }^{26}$ See Michele Colucci, Accordi bilaterali in campo migratorio tra Italia, Europa e Mediterraneo: l'evoluzione dal secondo dopoguerra a oggi, in Eugenia Ferragina (ed.), Rapporto...; Stefano Gallo, Le migrazioni interne nel Maghreb mediterraneo, dalla decolonizzazione al nuovo millennio, in Eugenia Ferragina (ed.), Rapporto...; Antonio M. Morone, Migranti e politiche di contenimento: il caso della Libia, in Eugenia Ferragina (ed.), Rapporto...
} 


\section{CHINA'S PRESENCE IN THE MEDITERRANEAN AND ITS IMPACTS: CENTRIPETAL IMPERIALISM}

The Chinese entry into the Mediterranean fits into this context, representing the final piece of the New Silk Roads. Announced in 2013 in Kazakhstan by President Xi Jinping, they developed a northern land corridor (the Silk Road Economic Belt) and a series of sea routes in the south between China and Europe (the $21^{\text {st }}$ Century Maritime Silk Road or MSR). Presented as One Belt, One Road (OBOR) in 2014 in front of the EU heads of government, this name was later replaced by the alternative Belt and Road Initiative. It involves many countries, which collectively account for more than half of the global GDP and $75 \%$ of the world's energy resources. The BRI's stated goal is to increase the transport networks between China and the European markets, although its ramifications are represented by Latin America and Africa. The sectors involved were not limited to logistics and trade: infrastructures only received $24 \%$ of the total funds, whereas $32 \%$ of them have so far been allocated to the energy sector (China is known to be an energy-intensive country). ${ }^{27}$

The main form of participation in the BRI is the signing of a specific Memorandum of Understanding (MoU). Among the G7 countries, Italy was the first one to sign, joining in March 2019. The peninsula offers a convenient way for Chinese goods to enter Europe; the Dragon mainly focuses on the northern Adriatic, as it does not have the difficulties in creating logistical lines with the hinterland that the Tyrrhenian Sea has, and, above all, it allows Mediterranean trade to connect with Europe's industrial and commercial engines (Germany, Austria, Hungary, and Poland). ${ }^{28}$ The projects in the northern Adriatic follow the acquisition of Piraeus, with Beijing obtaining the management of the main European transhipment port, which will be connected to Budapest through a new railway line via Skopje and Belgrade. ${ }^{29}$ The real Mediterranean bottleneck is still Suez; as a matter of fact, it has received China's main investments for the development and modernization

\footnotetext{
${ }^{27}$ See Alessia Amighini, Giulia Sciorati, Fact Checking: BRI, la nuova via della seta, ISPI, 2019.

${ }^{28}$ See Paolo Sellari, Scenari euroasiatici. Le Vie della Seta e la proiezione imperiale cinese, Edizioni Nuova Cultura, Rome 2020; Diego D’Amelio, II risveglio del porto di Trieste fra Mitteleuropa e Cina, in "Limes", XXVII, 10, 2019, pp. 263-272.

${ }^{29}$ See Huang Shan, China-Europe Maritime and Terrestrial Express Lines in Smooth Progress, CRI, May 13, 2017.
} 
of its port area through the launch of the Suez Canal Corridor Area Project (SCZone) and the introduction of the China-Egypt Suez Economic and Trade Cooperation Zone. ${ }^{30}$

Scholars' views about the Dragon's objectives and impacts on Mediterranean geopolitics are varied, to say the least. Some of them, while referring to an "Asian century", specified that China does not aspire to global hegemony, but rather to a leading and driving position in international economic development. ${ }^{31}$ Others, on the other hand, condemned the New Silk Roads as a "global invasion project"32, with imperialist ambitions carried forward thanks to an ad hoc use of financial resources. ${ }^{33}$ In fact, it is important to underline that the Chinese companies and funds involved in the BRI investments are mostly led (directly or indirectly) by the Beijing government. This could result in the risk of undue influence on the recipient countries; one example would be the forced return of the Uyghurs from Egypt to China in 2016-2017, which was carried out with the assistance of local security forces and justified by a cooperation agreement between the two countries for the suppression of Islamic terrorism. ${ }^{34}$ It is no coincidence that Greece and Egypt itself, among the main recipients of Chinese investments in the region, have openly supported Beijing against several international actions in defence of human rights. ${ }^{35}$

It is more difficult to determine what the economic impacts of the Chinese investments are and whether they favour unity or divisions in the area. According to some scholars, foreign direct investments (FDI) help the economic development of the host countries by increasing their capital and

${ }^{30}$ See AA.VV., The Suez Canal after the expansion. Analysis of traffic, competitiveness indicators, the challenges of the BRI and the role of the Free Zone, SRM and AlexBank, 2018.

${ }^{31}$ See Parag Khanna, The Future is Asian: Commerce, Conflict and Culture in the 21st Century, Simon \& Schuster, New York 2019.

${ }^{32}$ See Antonio Selvatici, La Cina e la Nuova Via della Seta. Progetto per un'invasione globale, Rubbettino, Soveria Mannelli 2018.

${ }^{33}$ See John Pomfret, China's debt traps around the world are a trademark of its imperialist ambitions, in "The Washington Post", August 27, 2019.

${ }^{34}$ See Human Rights Watch, Egypt: Don't Deport Uyghurs to China, July 2017.

${ }^{35}$ See Plamen Tonchev, Le relazioni sino-greche: contesto e prospettive, in "OrizzonteCina", IX, 3, pp. 16-20; Giulia Sciorati, Cina: la questione uigura nello Xinjiang, ISPI, 2019. 
bringing in best practises and new technologies; positive results in the Mediterranean and African countries were apparent at the turn of the crisis of 2008. ${ }^{36}$ Other scholars have analysed the possible negative effects of FDI, underlining their weight within the BRI. ${ }^{37}$ There is a risk that countries will give their raw materials away without gaining enough benefits, and that only investors will benefit. They can take advantage of local corruption and often unstable governments; usually, they do not hire local workers but only (or mostly) theirs. Moreover, they can limit access to new technologies' knowhow. Another big risk is represented by the "debt trap" in case the indebted governments do not have enough revenue generation, which "can generate a downward spiral that inevitably ends in the need for debt restructuring or reduction". ${ }^{38}$ However, real risks depend on the total amount of debt and the debt individual states owe to China: this mostly concerns countries in Southeast Asia and Sub-Saharan Africa and, in the Euro-Mediterranean area, the exceptional case of Montenegro. ${ }^{39}$

It can be seen how the Dragon does not exclude hard power, deploying the People's Liberation Army (PLA) and its Navy (PLA Navy), especially in those $\mathrm{BRI}$ areas with a higher strategic interest. For example, the naval base of Doraleh (Djibouti), whose construction began in 2016, allows China to have a stable presence in the Red Sea. ${ }^{40}$ However, Beijing relies more on its soft power. In order to overcome the accusations of being a threat to other countries and to propose itself as a reliable partner, China has funded many programmes to spread the Chinese language and culture, as well as a vast

\footnotetext{
${ }^{36}$ See Isaac Doku, John Akuma, John Owusu-Afriyie, Effect of Chinese foreign direct investment on economic growth in Africa, in "Journal of Chinese Economic and Foreign Trade Studies", X, 2, 2017, pp. 162-17; John Whalley, Aaron Weisbrod, The Contribution of Chinese FDI to Africa's Pre Crisis Growth Surge, in "Global Economy Journal", XII, 4, 2012, pp. 1-26.

${ }^{37}$ See Alessia Amighini, Finanza e potere lungo le Nuove Vie della Seta, Università Bocconi Editore, Milan 2021.

${ }^{38}$ See John Hurley, Scott Morris, Gailyn Portelance, Examining the Debt Implications of the Belt and Road Initiative from a Policy Perspective, CGD Policy Paper, Center for Global Development, Washington 2018.

${ }^{39}$ See Jeremy Garlik, The Impact of China's Belt and Road Initiative. From Asia to Europe, Routledge, Abingdon, 2020.

${ }^{40}$ See Alessia Amighini, Giulia Sciorati, Fact Checking...
} 
network of Confucius Institutes. ${ }^{41}$ Nevertheless, there are serious inconsistencies: the Dragon's companies abroad (including the ones in the Mediterranean) almost exclusively employ Chinese workers, who are not encouraged to settle in or fit in the local societies, in contrast with the intentions at the basis of cultural exchange initiatives. Moreover, as mentioned above, Beijing's indifference to the human rights issue risks affecting the countries that receive the investments as well.

All these elements support the hypothesis that the Chinese presence results in more divisions in the Mediterranean; this hypothesis seems to prevail in the heated debate among scholars.

To be fair, while not underestimating concerns regarding democracy and security, some scholars such as Alice Ekman highlight some elements showing the Dragon could seemingly favour more unity. ${ }^{42}$ Chinese investments concern both the southern and the northern shore, as evidenced by the acquisition of Piraeus, which managed to enter into competition with the ports of the Northern Range, with Rotterdam obtaining a contract with the American company Hewlett-Packard (HP) as its new distribution centre for central and southern Europe, North Africa, the Middle East, and Russia. Beijing's all-out policy, which is based on flexible, multilateral, and sector-specific mechanisms, fosters cohesion thanks to "group co-operation diplomacy": a model put forth again in various areas, such as the Forum on China-Africa Cooperation (FOCAC), the Forum on China-Arab States Cooperation Forum (CASCF), and the socalled " $17+1$ " with the countries of Central and Eastern Europe. ${ }^{43}$

The main flaw in such an analysis is that it focuses almost exclusively on the region's potential opportunities for economic development through

\footnotetext{
${ }^{41}$ See Audrey Dugué-Nevers, China and Soft Power: Building Relations and Cooperation, in "Contemporary Chinese Political Economy and Strategic Relations: An International Journal", III, 1, 2017, pp. 71-101; Mustafa Yağcl, Rethinking Soft Power in Light of China's Belt and Road Initiative, in "Uluslararasi iliskiler", LVII, 5, 2018, pp. 67-78.

42 See Alice Ekman, China in the Mediterranean: An Emergin Presence, in "Notes de l'Ifri", Ifri, February 2018.

${ }^{43}$ See Katarzyna W. Sidło, The Chinese Belt and Road Project in the Middle East and North Africa, in "IEMed Mediterranean Yearbook 2020", IEMed, Barcelona 2020, pp. 272-275; Hu Dawei, Analysis of the Group Cooperation Diplomacy of China, with Discussion of ChinaCEEC Cooperation, in "China Interntional Studies", XI, 6, 2015, pp. 40-57.
} 
Chinese investments, without giving due weight to the possible negative geopolitical impacts, which are underlined by another type of interpretation. According to scholars such as Christina Müller-Markus, Beijing has seemingly put aside its non-interference principle to protect its interests in the Mediterranean in a more active way, taking advantage of the EU, which it considers "a military uninfluental, politically divided, and ideologically weakened actor". ${ }^{44}$ Agreements with Athens would play a central role: "Greece's geographical and diplomatic proximity - with Europe and NATO on one side and the Middle East on the other - makes it an attractive ally in the strategic vision pursued by China". ${ }^{45}$ The ability of China to increase divisions through the use of hard power, as in the case of the naval base in Djibouti ${ }^{46}$ or its army's support to the Arab states promised in the Arab Policy Paper of 2016, has been pointed out. ${ }^{47}$ As remarked by Nadia Schadlow, Beijing has taken advantage of the internal tensions within NATO and the EU to change the status quo: "China's presence and active investments in the region have divided friends and provided them with alternatives to the EU and the United States". ${ }^{4}$

This second interpretation has the merit of highlighting the prevalence of division elements among the effects of the Chinese foray into the Mediterranean. However, it has the limit of overstressing the importance of hard power, almost overshadowing China's preference for soft power and for win-win agreements. These aspects regain their centrality, for example, in the analysis of Adel A. Ghafar and Anna L. Jacobs. ${ }^{49}$ Focusing on Beijing's bilateral agreements with Morocco, Algeria, and Egypt, they underline their primarily economic and trade nature, breaking the "debt book diplomacy" stereotype. China has influence on the states of the southern shore as they consider it a valid alternative to the US and European countries. It is by taking advantage

${ }^{44}$ Christina Müller-Markus, China Moors in the Mediterranean: A Sea of Opportunities for Europe?, in "Notes Internacionals", VIII, 156, pp. 1-4.

${ }^{45}$ Ibid.

${ }^{46}$ Alessia Amighini, Giulia Sciorati, Fact Checking...

${ }^{47}$ People's Republic of China, Arab Policy Paper, Beijing, 2016.

${ }^{48}$ Nadia Schadlow, China in the Mediterranean and Implications for the United States and Europe, in "Strategika", VIII, 62, 2020, pp. 31-33.

${ }^{49}$ Adel Abdel Ghafar, Anna L. Jacobs,, China in the Mediterranean: Implications of expanding Sino-North Africa relations, Brooking Institution, Washington 2020. 
of their mistakes and indecisiveness that Beijing has succeeded in presenting a new model of practical and flexible development that has the advantage of not requiring democratic reforms and sticking to the non-interference principle. North African and Middle Eastern countries' getting closer to China with regard to diplomacy and security represents only the next step in integration, and Beijing would not intend to confront the US from a political and military point of view. As a matter of fact, its entry into the Mediterranean is based on a "balance of power" whose aim would be, neither more nor less, to protect its own interests in the region.

This position is in line with the one expressed in 2019 by Jon B. Alterman in front of a US House Subcommittee. ${ }^{50}$ China would not aim to replace the United States in the Middle East. On the contrary, it would be interested in having Washington incur the costs of keeping order in the region. Beijing would "content itself" with the benefits of promoting its relationships with the countries in the area, especially with the ones on the southern shore, which consider it an alternative partner, the advantage being that it was not their colonizer. Beijing only offers them agreements with their full consent, without further conditions. The Dragon not only does not affect these countries' traditions, but it has also received the support of local populations as it brought in new infrastructures and technologies. Alterman defines this as "Imperialism 3.0 (or perhaps Mercantilism 2.0)" 51 as China manages to make its partners dependent in an indirect way. This strategy gives a central role to digital technology, as evidenced by the $5 \mathrm{G}$ case. Beijing, concludes Alterman, questions the US certainties by "seeking ways to compete without becoming a rival". ${ }^{2}$

In conclusion, we think we can integrate this set of interpretations by defining Chinese space as a centripetal imperial one: the Dragon is pushed by the global geopolitical reality to project itself beyond its borders by adopting neo-colonial policies to protect its own national interests - primarily economic ones - without imposing a predetermined political and cultural formula and only intervening if strategically necessary.

\footnotetext{
${ }^{50}$ See Jon B. Alterman, Chinese and Russian Influence in the Middle East, in "Middle East Policy", XXVI, 2, 2019, pp. 129-136. It is the House Foreign Affairs Subcommittee on the Middle East, North Africa, and International Terrorism.

${ }^{51}$ Ibid.

52 Ibid.
} 


\section{BEIJING'S PENETRATION IN THE BALKANS}

In the described framework, a particularly interesting case study is represented by Beijing's penetration of the Balkans. If it was negligible until around $2010^{53}$, things have remarkably changed in the following years. As a result, given their numerous and uneven ramifications, Chinese activities in the area require proper contextualization in order to be understood. The Balkans already have highly discussed geographical borders and, within them, they have a great variety of economic, political, and cultural situations. Moreover, as it has been remarked, the Dragon has not elaborated on a specific strategy for the countries in this area. ${ }^{54}$ On the other hand, they have been included in the wider scope of the Central and Eastern European (CEE) countries, with which China created the "16+1" format in 2016, which then became "17+1" in 2019, after Greece had joined. Greece, which does not geographically fall within the so-called CEE area, has been involved because it borders three countries (Albania, Bulgaria, and North Macedonia), which belong to it with full rights.

The accession of Athens to the $17+1$ forum allows for a reflection on the nature of such an initiative and on the interests pushing China to carry it forward. Plamen Tonchev tried to go beyond "the idea that the expansion of Beijing's influence has to be ascribed to the growth of its investments in the region", arguing that the profound motivations for the expansion have "less to do with the financial resources mobilised by China in the Mediterranean and more with the emotions and perceptions that China arouses in public opinion and in local political life". ${ }^{55}$ In support of its own theory, the scholar mentions a series of surveys which show how citizens of the Balkan countries are disappointed by the EU with regard to globalisation and, even if they do not have a positive opinion about social and working life in China, they have a very favourable opinion about it as an economic partner. ${ }^{56}$ Tonchev's interpretation

${ }^{53}$ See Anastas Vangeli, China's Belt and Road in the Balkans in the Post-COVID-19 Era, IEMed Mediterranean Yearbook, 2020.

${ }^{54}$ See Wouter Zweers, Vladimir Shopov, Frans-Paul van der Putten, Mirela Pektova, Maarten Lemstra, China and the EU in the Western Balkans. A zero-sum game?, Clingendael, 2020.

${ }^{55}$ See Plamen Tonchev, Le relazioni sino-greche: contesto e prospettive, in "OrizzonteCina", IX, 3, 2018 pp. 16-20.

${ }^{56}$ See Plamen Tonchev, China's Image in Greece. 2008-2018, Institute of International Economic Relations, 2018. 
is supported by a theoretical framework offered by Andrea Ghiselli. When referring to Chinese-Balkan relations, he mentions a series of contributions on the use of narratives for the purpose of geopolitical influence. ${ }^{57}$

However, these interpretations are weakened by the fact that they excessively underestimate the role played by infrastructure in the Dragon's economic and expansion policies. Infrastructural projects in the Balkan countries (especially the Western ones) have often been met with scepticism by European and American investors who tend to label them as too expensive and risky, as well as not profitable enough, also because they almost exclusively pertain to the public sector. A report by the International Monetary Fund (IMF) has clearly stated that such projects should not be considered as "a substitute for a wide range of structural reforms and prudent macrofinancial policies" needed for the region's development. ${ }^{58}$ These countries have thus found an attractive and ready alternative in the Chinese investment proposals, which are by no means concerned about road construction in mountainous areas and are interested in maximising connectivity in territories where it is possible to exploit economic-commercial potential. The Chinese approach is well represented by the motto "if one wants to develop, one should build the roads first". ${ }^{59}$

Besides, the cooperation forum between China and the Central and Eastern countries, as recognised by Chinese institutions themselves, has to be considered an integral part of the BRI plan. ${ }^{60}$ This becomes apparent if one considers that 22 countries within the geographical area under discussion adhere to the Belt and Road Initiative more or less officially. They are more than the ones taking part in the " $17+1$ " format where, for obvious reasons of expediency, Beijing has not involved those post-Soviet states which are still

${ }^{57}$ See Andrea Ghiselli, L'importanza di sapersi raccontare: le sfide della Belt and Road Initiative dall'Asia ai Balcani, in "OrizzonteCina", IX, 3, 2018, pp. 3-10.

${ }^{58}$ See Ruben Atoyan, Dóra Benedek, Public infrastructure in the Western Balkans: a highway to higher income, International Monetary Fund, 2018.

${ }^{59}$ See Xin Chen, Connectivity in China and Europe: what lessons can be learned, in Māris Andžāns (ed.), Afterthoughts: Riga 2016 International Forum of China and Central and Eastern European Countries, Latvian Institute of International Affairs, 2016, pp. 40-43.

${ }^{60}$ See State Information Center, "Belt and Road" Country Cooperation Evaluation Report, 2016. 
in the Russian orbit (such as Armenia, Azerbaijan, Belarus, Georgia, Moldova, and Ukraine). Some scholars, such as Jeremy Garlik, tend to downsize the importance of Central-Eastern Europe and the Balkans within the BRI. ${ }^{61}$ According to such interpretations, China's interests would be centred in countries that are closer ${ }^{62}$ to it and, at most, in the countries of Western Europe. $^{63}$ This hypothesis is apparently supported by the fact that Chinese investments currently account for less than $1 \%$ of the total FDI in the region ${ }^{64}$, whereas around $90 \%$ of Chinese funding is always directed to Western Europe (especially Germany, France, and the United Kingdom). ${ }^{65}$

However, this view does not take into account the strategic importance of the Balkans as a potential link between the arrival point of the Maritime Silk Road in the Mediterranean and the promising and ever-growing industrial and commercial region of Central-Eastern Europe. The area would represent an ideal entry point for the wider and more developed market of Western Europe, and it is also a manufacturing space that, in the context of fairly strong institutions, offers a skilled workforce and acceptable wages. ${ }^{66}$ Related to " $17+1$ " and integrated within the BRI, the China-Europe Land-Sea Express Route (LSER) finds its own central role, that is, a railway corridor designed for the transport of containerized goods from the port of Piraeus to Hungary and the Czech Republic through North Macedonia and Serbia. ${ }^{67}$ This main project, managed by the Chinese COSCO, is accompanied by many others which are controlled, more or less directly, by the Dragon: the Pelješac Bridge and the Bar-Boljare highway in Montenegro, both entrusted to the China Road and

${ }^{61}$ See Jeremy Garlik, The Impact of China's Belt and Road Initiative. From Asia to Europe, Routledge, Abingdon, 2020, pp. 178-184.

62 See Kerry Brown, China's World: What Does China Want?, I. B. Tauris, London and New York 2017.

${ }^{63}$ See Richard Turcsányi, China is raising its flag in Central and Eastern Europe, East Asia Forum, 2018.

${ }^{64} \mathrm{Ibid}$.

${ }^{65}$ See Derek Scissors, China Global Investment Tracker (CGIT), The American Enterprise Institute and the Heritage Foundation, 2019; People's Republic of China, Statistical Bulletin of China's Outward Foreign Direct Investment, Beijing 2017.

${ }^{66}$ See Weiqing Song (ed.), China's Relations with Central and Eastern Europe. From "Old Comrades" to New Partners, Routledge, Abingdon 2018.

${ }^{67}$ See Wouter Zweers et. al., China and the EU... 
Bridge Corporation (CRBC); the A-2 and A-4 Highway sections in North Macedonia; the Počitelj - Zvirovići subsection in Bosnia and Herzegovina managed by the Construction Engineering Corporation (CSCEC), etc. ${ }^{68}$

Chinese penetration in the Balkans, however, is not merely linked to logistics and transport. Think of Geo-Jade, a Chinese private company that entered the oil market in 2013 and acquired Bankers Petroleum for €385 million in 2016. Despite being a former Canadian company, it currently produces around $95 \%$ of Albania's crude oil, accounting for $11 \%$ of the country's exports. ${ }^{69}$ Another big operation was the acquisition of Zelezara Smederevo by the state-owned Chinese Hesteel Group company for $€ 46$ million. After the acquisition, the steel manufacturing company became the first Serbian exporter, thus remarkably fostering local employment. Chinese FDI in Serbia went from 7.32\% of the total amount in 2016 to $14.82 \%$ in 2018.

The privileged relationship between Belgrade and Beijing is confirmed by the choice of the latter not to support the recognition of Kosovo at an international level (as it is, on principle, against independent movements, considering that it is dealing with them in Xinjiang, Tibet, and Taiwan, which it considers as its rebel provinces). ${ }^{70}$ Such a circumstance has reinforced European concerns regarding potential political liaisons between the Dragon and the countries of the Western Balkans, in particular the fact that the nonconditionality of investments and the combination of capitalism and political dictatorship of the Chinese model could dangerously attract some states that are or could become candidates for EU membership. This led the European Commissioner, Johannes Hahn, to warn that the People's Republic could turn the countries into "Trojan horses". ${ }^{71}$ However, it must also be mentioned that although Beijing does not have any official relations with Kosovo and does not promote its recognition, unlike Russia, it did not oppose it either. ${ }^{72}$ Moreover, considering that China's position is primarily intended to seek support against the recognition of Taiwan, this case well represents what we defined as

\footnotetext{
${ }^{68} \mathrm{Ibid}$. See also Weiqing Song (ed.), China's Relations...

${ }^{69}$ See Wouter Zweers et. al., China and the EU...

70 Ibid.

${ }^{71}$ See Dragan Pavlićević, Unione Europea e Cina nei Balcani occidentali: quali agende politiche e quali vettori di influenza?, in "OrizzonteCina", IX, 3, 2018, pp. 16-24.

72 See Wouter Zweers et. al., China and the EU...
} 
centripetal imperialism, namely, the Dragon's tendency to only use interventionism for the protection of its direct interests. Finally, as pointed out, the communist past of the Balkans made these countries quite wary of Chinese official propaganda and therefore unwilling to passively follow its models. ${ }^{73}$

Others seem to be the main critical issues regarding China's presence in the Balkans, and they are well represented by two cases. The first one is related to the Bar-Boljare highway: Montenegro owes to China's ExportImport (Exim) Bank (which financed the project) $€ 671$ million, that is, $22 \%$ of the country's total foreign debt, and which accounts for $63 \%$ of its GDP. Podgorica is not able to repay and the EU has refused to help, with the risk that this could trigger the "debt trap", an exceptional case in the region. ${ }^{74}$ The second case is the Kichevo-Ohrid highway in North Macedonia, financed by the Exim Bank itself and entrusted to Sinohydro. The accusations of corruption against some officials of the Macedonian government raised concerns about the fairness of the project's tender, which was later temporarily interrupted. ${ }^{75}$ In general, also in the Balkan area, the problems arising from Chinese financing do not seem to be sufficiently explained by the interpretations of Beijing's potential ambitions of subjugation, but they have a more convincing interpretation (as already proposed by Deborah Brautigam in 200976) in "much less malevolent intentions and still unresolved planning mistakes by China". ${ }^{77}$ Within this context, an EU comeback should be considered: by changing some conditions for new members to join and by launching initiatives like the "Berlin process" for an enlargement involving the Balkans, it makes future developments in the area more complicated. ${ }^{78}$

\footnotetext{
${ }^{73}$ See Weiqing Song (ed.), China's Relations...

${ }^{74}$ See Dragan Pavlićević, Unione Europea e Cina...; Wouter Zweers et. al., China and the EU...; Hans von der Burchard, EU rebuffs Montenegro plea to help repay \$1B Chinese highway loan, in "Politico", December 21, 2021.

75 See Anastas Vangeli, La cooperazione per lo sviluppo delle infrastrutture nei Balcani: sotto l'egida della Cina, per volontà locale, in "OrizzonteCina", IX, 3, 2018, pp. 11-15; Wouter Zweers et. al., China and the EU...

${ }^{76}$ See Deborah Brautigam, The Dragon's Gift: the real story of China in Africa, Oxford University Press, Oxford and New York 2009.

77 See Andrea Ghiselli, L'importanza di sapersi raccontare...

${ }^{78}$ See Dragan Pavlićević, Unione Europea e Cina...
} 
To conclude, as we have seen, it is not possible to understand China's presence in the Mediterranean without bearing in mind the peculiarity of the region, as given by its several divisions. Considering the Western failures, in such a context, Beijing is an attractive alternative partner, especially for the countries (on both sides of the sea) that are most in need of resources. Indeed, China's investments benefit from the BRI's brand and from not asking recipient countries for any demanding reforms. Apart from the opposing analyses of the scholars, the case study of the Balkans confirms our geopolitical interpretation of a Chinese centripetal imperialism: the Dragon is ready to offer its capitals in exchange for a penetration which, despite its neo-colonial aspect, does not want to impose a predetermined political and cultural formula.

\section{BIBLIOGRAPHY}

AA.VV., The Suez Canal after the expansion. Analysis of traffic, competitiveness indicators, the challenges of the BRI and the role of the Free Zone, SRM and AlexBank, 2018. Roberto Aliboni, L'evoluzione geopolitica nel Medioriente, in Eugenia Ferragina (ed.), Rapporto sulle economie del Mediterraneo. Edizione 2018, Istituto di Studi sulle Società del Mediterraneo, Rome 2018.

Carlo Almirante, Considerazioni interlocutorie su uno stimolante convegno internazionale, in Guerino D'Ignazio, Nicola Fiorita, Silvio Gambino, Francesco Raniolo, Alberto Ventura (eds.), Transizioni e democrazia nei Paesi del Mediterraneo e del vicino Oriente, Edizioni Periferia, Cosenza 2014, pp. 401-411.

Jon B. Alterman, Chinese and Russian Influence in the Middle East, in "Middle East Policy", XXVI, 2, 2019, pp. 129-136. It is the House Foreign Affairs Subcommittee on the Middle East, North Africa, and International Terrorism.

Alessia Amighini, Giulia Sciorati, Fact Checking: BRI, la nuova via della seta, ISPI, 2019.

Alessia Amighini, Finanza e potere lungo le Nuove Vie della Seta, Università Bocconi Editore, Milan 2021.

Ruben Atoyan, Dóra Benedek, Public infrastructure in the Western Balkans: a highway to higher income, International Monetary Fund, 2018. 
Thompson Ayodele, Olusegun Sotola, China in Africa: An Evaluation of Chinese Investment, Working Paper, IPPA, 2014.

Francesco Bertonelli, II nostro mare: studio della situazione politica militare dell'Italia nel Mediterraneo, R. Bemporad \& Figlio editori, Florence 1930.

Deborah Brautigam, The Dragon's Gift: the real story of China in Africa, Oxford University Press, Oxford and New York 2009.

Kerry Brown, China's World: What Does China Want?, I. B. Tauris, London and New York 2017.

Matthias Busse, Steffen Gröning, The resource curse revisited: governance and natural resources, in "Public Choice", CXLV, 1, 2013, pp. 1-20.

Susanna Cafaro, L'Unione per il Mediterraneo, in "Studi sull'integrazione europea", V, 1, 2010, p. 105-128.

Susanna Cafaro, La dimensione mediterranea nelle relazioni esterne dell'Unione dopo la primavera araba, in "Cultura giuridica e diritto vivente", I, 1, 2014, pp. 1-18.

Salvatore Capasso, Introduzione. I paesi del Mediterraneo tra disuguaglianza e convergenza: sviluppo economico, sostenibilità e migrazioni, in Eugenia Ferragina (ed.), Rapporto sulle economie del Mediterraneo. Edizione 2018, Istituto di Studi sulle Società del Mediterraneo, Rome 2018.

Angelo Francesco Carlucci, La Turchia e le "Primavere arabe", in Guerino D’Ignazio, Nicola Fiorita, Silvio Gambino, Francesco Raniolo, Alberto Ventura (eds.), Transizioni e democrazia nei Paesi del Mediterraneo e del vicino Oriente, Edizioni Periferia, Cosenza 2014, pp. 387-392.

Michela Ceccorulli, La dimensione marittima dell'Unione Europea nel Mediterraneo allargato. Opportunità, rischi e prospettive, CeMiSS, 2016.

Francesco Cirillo, Interessi russi nel Mediterraneo Orientale, in Mediterranean Sea: Current Trends and Future Challenges, Association of Studies, Research and Internationalization in Eurasia and Africa, "Geopolitical Report", III, 4, 2018, pp. 69-82.

Michele Colucci, Accordi bilaterali in campo migratorio tra Italia, Europa e Mediterraneo: l'evoluzione dal secondo dopoguerra a oggi, in Eugenia Ferragina (ed.), Rapporto sulle economie del Mediterraneo. Edizione 2018, Istituto di Studi sulle Società del Mediterraneo, Rome 2018. 
Antoine Courban, Essere cristiani in Medio Oriente, in "Aggiornamenti sociali", LXVII, 1, 2016, pp. 28-38.

Diego D’Amelio, II risveglio del porto di Trieste fra Mitteleuropa e Cina, in "Limes", XXVII, 10, 2019, pp. 263-272.

Hu Dawei, Analysis of the Group Cooperation Diplomacy of China, with Discussion of China-CEEC Cooperation, in "China Interntional Studies", XI, 6, 2015, pp. 40-57.

Anna Maria Delvecchio, Grecia e Turchia in competizione nel Mediterraneo orientale: il caso emblematico di Cipro, in "Cultura giuridica e diritto vivente", VII, 3, 2020, pp. 1-10.

Isaac Doku, John Akuma, John Owusu-Afriyie, Effect of Chinese foreign direct investment on economic growth in Africa, in "Journal of Chinese Economic and Foreign Trade Studies", X, 2, 2017, pp. 162-171.

Audrey Dugué-Nevers, China and Soft Power: Building Relations and Cooperation, in "Contemporary Chinese Political Economy and Strategic Relations: An International Journal", III, 1, April-May 2017, pp. 71-101.

Alice Ekman, China in the Mediterranean: An Emergin Presence, in "Notes de I'Ifri", Ifri, February 2018.

Anna Maria Ferragina, Giulia Nunziante, Disparità e ineguaglianze tra i territori all'interno dell'area Mediterranea, in Eugenia Ferragina (ed.), Rapporto sulle economie del Mediterraneo. Edizione 2018, Istituto di Studi sulle Società del Mediterraneo, Rome 2018.

Eugenia Ferragina, Europa e Mediterraneo: le potenzialità di integrazione e le strategie di rilancio della politica mediterranea, in Eugenia Ferragina, Paolo Malanima (eds.), Rapporto sulle economie del Mediterraneo. Edizione 2014, Istituto di Studi sulle Società del Mediterraneo, Rome 2014.

Eugenia Ferragina, Desiree Ada Ludmilla Quagliarotti, Stabilità e sicurezza nel Mediterraneo tra vincoli ambientali e divari socio-economici, in Eugenia Ferragina (ed.), Rapporto sulle economie del Mediterraneo. Edizione 2018, Istituto di Studi sulle Società del Mediterraneo, Rome 2018.

Luca Forte, Giovanni Canitano, Maria Rosaria Carli, Crescita economica, produzione manifatturiera e commercio estero nei paesi del Mediterraneo: differenze e complementarità tra paesi euromediterranei e paesi della sponda sud ed est del Bacino, in Eugenia Ferragina (ed.), 
Rapporto sulle economie del Mediterraneo. Edizione 2018, Istituto di Studi sulle Società del Mediterraneo, Rome 2018.

Giuseppe Gagliano, Mediterraneo orientale: una disputa geoeconomica e geopolitica, in "Rivista marittima", CLIV, 2, 2021, pp. 48-55.

Stefano Gallo, Le migrazioni interne nel Maghreb mediterraneo, dalla decolonizzazione al nuovo millennio, in Eugenia Ferragina (ed.), Rapporto sulle economie del Mediterraneo. Edizione 2018, Istituto di Studi sulle Società del Mediterraneo, Rome 2018.

Jeremy Garlik, The Impact of China's Belt and Road Initiative. From Asia to Europe, Routledge, Abingdon, 2020.

Adel Abdel Ghafar, Anna L. Jacobs,, China in the Mediterranean: Implications of expanding Sino-North Africa relations, Brooking Institution, Washington 2020.

Giorgio Giorgerini, Riccardo Nassigh, La relatività delle forze nell'area del Mediterraneo Allargato, in C. M. Santoro (ed.), II XXI Secolo, Centro Militare di Studi Strategici, Milan 2002.

Andrea Ghiselli, L'importanza di sapersi raccontare: le sfide della Belt and Road Initiative dall'Asia ai Balcani, in "OrizzonteCina", IX, 3, 2018, pp. 3-10.

Maria Eleonora Guasconi, La politica mediterranea dell'Unione Europea: l'occasione perduta del partenariato euro-mediterraneo, in Sante Cruciani, Maurizio Ridolfi (eds.), L'Unione Europea e il Mediterraneo. Relazioni internazionali, crisi politiche e regionali (1947-2016), FrancoAngeli, Milan 2017, pp. 199-212.

Bernard Heyberger, Les Chrétiens au Proche-Orient, Payot et Rivages, Paris 2013.

Andrew Hess, The Forgotten Frontier: A History of the Sixteenth Century IberoAfrican Frontier, University Chicago Press, Chicago 1978.

Huang Shan, China-Europe Maritime and Terrestrial Express Lines in Smooth Progress, CRI, May 13, 2017.

Human Rights Watch, Egypt: Don't Deport Uyghurs to China, July 2017.

Samuel Phillips Huntington, The Clash of Civilizations and the Remaking of World Order, Simon \& Schuster, New York 1996. 
John Hurley, Scott Morris, Gailyn Portelance, Examining the Debt Implications of the Belt and Road Initiative from a Policy Perspective, CGD Policy Paper, Center for Global Development, Washington 2018.

Aleksandr Irkhin, Olga Moskalenko, Russia's Foreign Policy in the Great Mediterranean: Prospects and Constraints, in "Geopolitics Quarterly", XV, 4, Winter 2020, pp. 110-121.

Alessandro Isoni, Da Barcellona a Marsiglia. Le politiche dell'Unione europea nel Mediterraneo, in Susanna Cafaro (ed.), Le relazioni euro-mediterranee. Dai primi accordi all'Unione per il Mediterraneo, ESI, Naples 2013, p. 1 and ff.

Jana Jabbour, Le retour de la Turquie en Méditerranée: la «profondeur stratégique» turque en Méditerranée préet post-printemps arabe, in "Cahiers de la Méditerranée", XLV, 89, 2014, pp. 45-56.

Parag Khanna, The Future is Asian: Commerce, Conflict and Culture in the 21st Century, Simon \& Schuster, New York 2019.

Alexandre Koyré, Dal mondo del pressappoco all'universo della precisione, Einaudi, Turin 2000.

Giuliana Laschi, La Cee e il Mediterraneo: l'avvio delle politiche verso i paesi terzi della sponda sud, in Sante Cruciani, Maurizio Ridolfi (eds.), L'Unione Europea e il Mediterraneo. Relazioni internazionali, crisi politiche e regionali (1947-2016), FrancoAngeli, Milan 2017, pp. 89-110.

Chiara Lovotti, La Russia in Medio Oriente. Una presenza destinata a durare?, in "Osservatorio di politica internazionale", 79, 2018.

Samir Makdisi, Sulle disparità economiche e politiche prevalenti e sulle prospettive di una stretta integrazione di una regione euro-mediterranea, in Eugenia Ferragina (ed.), Rapporto sulle economie del Mediterraneo. Edizione 2018, Istituto di Studi sulle Società del Mediterraneo, Rome 2018. Jakob Mardell, China's Economic Footprint in the Western Balkans, Policy Brief, Bertelsmann Stiftung, 2020.

Fabien Merz, Trouble with Turkey in the Eastern Mediterranean, in "CSS Analyses in Security Policy", n. 275, CSS ETH Zürich, December 2020, pp. 1-4. 
Antonio M. Morone, Migranti e politiche di contenimento: il caso della Libia, in Eugenia Ferragina (ed.), Rapporto sulle economie del Mediterraneo. Edizione 2018, Istituto di Studi sulle Società del Mediterraneo, Rome 2018.

Christina Müller-Markus, China Moors in the Mediterranean: A Sea of Opportunities for Europe?, in "Notes Internacionals", VIII, 156, pp. 1-4.

Paolo Naso, L'incognita post-secolare. Pluralismo religioso, fondamentalismi, laicità, Guida Editori, Naples 2015.

Vali Nasr, The Shia Revival: How Conflicts within Islam Will Shape the Future, W.W. Norton \& Company, New York 2016.

Stefania Panebianco, L'Unione Europea nel Mediterraneo: oltre la primavera araba, in Guerino D'Ignazio, Nicola Fiorita, Silvio Gambino, Francesco Raniolo, Alberto Ventura (eds.), Transizioni e democrazia nei Paesi del Mediterraneo e del vicino Oriente, Edizioni Periferia, Cosenza 2014, pp. 287-310.

Dragan Pavlićević, A Power Shift Underway in Europe? China's Relationship with Central and Eastern Europe Under the Belt and Road Initiative, in Xing Li, Mapping China's 'One Belt One Road' Initiative, Palgrave Macmillan, London 2018, pp. 249-278.

Dragan Pavlićević, Unione Europea e Cina nei Balcani occidentali: quali agende politiche e quali vettori di influenza?, in "OrizzonteCina", IX, 3, 2018, pp. 16-24.

People's Republic of China, Arab Policy Paper, Beijing, 2016.

People's Republic of China, Statistical Bulletin of China's Outward Foreign Direct Investment, Beijing 2017.

John Pomfret, China's debt traps around the world are a trademark of its imperialist ambitions, in "The Washington Post", August 27, 2019.

Pier Paolo Ramoino, Fondamenti di strategia navale, Edizioni Forum Relazioni Internazionali, Rome 1999.

Pier Paolo Ramoino, La NATO e il "Mediterraneo allargato": primavera araba, intervento in Libia, partnerships, in "Quaderni del Dipartimento di Scienze Politiche. Università del Sacro Cuore", II, 4, 2012, pp. 73-84.

Anders Fogh Rasmussen, NATO and the Arab Spring, Speech by the NATO Secretary General during the Forum for New Diplomacy hosted by Carnegie Europe, Bruxelles, June 1, 2011. 
Giulia Sciorati, Cina: la questione uigura nello Xinjiang, ISPI, 2019.

Derek Scissors, China Global Investment Tracker (CGIT), The American Enterprise Institute and the Heritage Foundation, 2019.

Paolo Sellari, Scenari euroasiatici. Le Vie della Seta e la proiezione imperiale cinese, Edizioni Nuova Cultura, Rome 2020.

Antonio Selvatici, La Cina e la Nuova Via della Seta. Progetto per un'invasione globale, Rubbettino, Soveria Mannelli 2018.

Nadia Schadlow, China in the Mediterranean and Implications for the United States and Europe, in "Strategika", VIII, 62, 2020, pp. 31-33.

Katarzyna W. Sidło, The Chinese Belt and Road Project in the Middle East and North Africa, in "IEMed Mediterranean Yearbook 2020", IEMed, Barcelona 2020, pp. 272-275.

SRM, MED \& Italian Energy Report. Risorse, flussi e strategie energetiche dell'Italia tra Europa e Mediterraneo, First Annual Report, 2019.

SRM, Resilienza e Sviluppo nel Mezzogiorno: settori, aree e linee prospettiche, Report prepared for the Aspen Institute Italia Conference of December 3, 2020 "Il Mezzogiorno d'Italia: chiave di rilancio per l'economia italiana?", 2020.

State Information Center, "Belt and Road" Country Cooperation Evaluation Report, 2016.

Plamen Tonchev, China's Image in Greece. 2008-2018, Institute of International Economic Relations, 2018.

Plamen Tonchev, Le relazioni sino-greche: contesto e prospettive, in "OrizzonteCina", IX, 3, 2018 pp. 16-20.

Massimiliano Trentin, Le Comunità Europee e gli Stati arabi nei «lunghi anni settanta»: economia, politica e potere, in Sante Cruciani, Maurizio Ridolfi (eds.), L'Unione Europea e il Mediterraneo. Relazioni internazionali, crisi politiche e regionali (1947-2016), FrancoAngeli, Milan 2017, pp. 129-148.

Richard Turcsányi, China is raising its flag in Central and Eastern Europe, East Asia Forum, 2018.

Anastas Vangeli, La cooperazione per lo sviluppo delle infrastrutture nei Balcani: sotto l'egida della Cina, per volontà locale, in "OrizzonteCina", IX, 3, 2018, pp. 11-15. 
Anastas Vangeli, China: A New Geoeconomic Approach to the Balkans, in Florian Bieber, Nikolaos Tzifakis, The Western Balkans in the World: Linkages and Relations with External Actors, Routledge, Abingdon 2019.

Anastas Vangeli, China's Belt and Road in the Balkans in the Post-COVID-19 Era, IEMed Mediterranean Yearbook, 2020.

Alberto Ventura, Le Rivoluzioni prevedibili. Per una analisi storica delle "Primavere arabe", in Guerino D'Ignazio, Nicola Fiorita, Silvio Gambino, Francesco Raniolo, Alberto Ventura (eds.), Transizioni e democrazia nei Paesi del Mediterraneo e del vicino Oriente, Edizioni Periferia, Cosenza 2014, pp. 333-344.

Weiqing Song (ed.), China's Relations with Central and Eastern Europe. From "Old Comrades" to New Partners, Routledge, Abingdon 2018.

Hans von der Burchard, EU rebuffs Montenegro plea to help repay $\$ 1 B$ Chinese highway loan, in "Politico", December 21, 2021.

John Whalley, Aaron Weisbrod, The Contribution of Chinese FDI to Africa's Pre Crisis Growth Surge, in "Global Economy Journal", XII, 4, 2012, pp. 1-26.

Xin Chen, Connectivity in China and Europe: what lessons can be learned, in Māris Andžāns (ed.), Afterthoughts: Riga 2016 International Forum of China and Central and Eastern European Countries, Latvian Institute of International Affairs, 2016, pp. 40-43.

Mustafa Yağcl, Rethinking Soft Power in Light of China's Belt and Road Initiative, in "Uluslararasi iliskiler", LVII, 5, 2018, pp. 67-78.

Wouter Zweers, Vladimir Shopov, Frans-Paul van der Putten, Mirela Pektova, Maarten Lemstra, China and the EU in the Western Balkans. A zero-sum game?, Clingendael, 2020. 